Federal Reserve Bank of Minneapolis

Research Department Staff Report 439

February 2010

\title{
Competition and Productivity: A Review of Evidence*
}

Thomas J. Holmes

University of Minnesota, Federal Reserve Bank of Minneapolis, and National Bureau of Economic Research

James A. Schmitz, Jr.

Federal Reserve Bank of Minneapolis

ABSTRACT

Does competition spur productivity? And if so, how does it do so? These have long been regarded as central questions in economics. This essay reviews the literature that makes progress toward answering both questions.

*We thank Tim Bresnahan, Douglas Clement, and Richard Rogerson. The views expressed herein are those of the authors and not necessarily those of the Federal Reserve Bank of Minneapolis or the Federal Reserve System. 


\section{INTRODUCTION}

Does competition spur productivity? And if so, how? These have long been regarded as central questions in economics, and major figures in the profession, such as Schumpeter (1942), Stigler (1957), and Arrow (1962), have weighed in on the debate. The extent of competition can be influenced by policy decisions, so understanding how competition impacts productivity and, in turn, living standards is of more than academic importance.

To fully answer these questions of whether, and how, an increase in competition impacts productivity, two issues must be addressed. First, at a basic level, we must define what we mean by an "increase in competition." Second, given a (well-defined) change in competition, and given that we find productivity changes, we must understand the mechanisms through which competition impacts productivity. Both issues present substantial challenges.

To see the difficulties involved with the first issue, defining an increase in competition, consider this example. Suppose an industry is initially protected by a government-imposed barrier that blocks the entry of large-scale, highly productive firms. (Think of recent efforts to block Wal-Mart's entry in some urban locations.) Initially, many small firms are in the industry. Imagine that the barrier is lifted and that one large, highly productive firm enters and drives out a multitude of small, less productive firms. Suppose further that researchers analyzing this issue, as is often the case, have ready access to market share data but have no information on government policies toward entry. In this case, many researchers would define this industry as having become less competitive, given the increase in measured market concentration. But the change in concentration is being driven by the elimination of an entry barrier, which can sensibly be viewed as an increase in competition. This example is not anomalous, as we discuss further below, and illustrates the difficulty of using industry statistics such as concentration to define what we mean by increases in competition.

Now we turn to the difficulties with the second issue, namely, understanding the mechanisms 
through which competition impacts productivity. Suppose we find that after a well-defined increase in competition, productivity increases both because of some inefficient plants closing and because of surviving plants increasing their productivity. The theory of how competition leads to reallocation, of the closing of inefficient plants, is well understood. But despite having attracted much interest over many years, the theory of how competition can make a given plant more efficient is not fully worked out. Leibenstein (1966) made a name for himself on this issue, not by developing a coherent theory but rather in coming up with a label (albeit an awkward one!) that stuck. Leibenstein asserted that monopolists suffer from $X$-inefficiency, meaning they have low total factor productivity (TFP), and that exposure to competition eliminates this disease. ${ }^{1}$ The conundrum that is difficult to crack is this: if a monopolist could produce the same output with less inputs, why doesn't it do so and pocket the savings as profit? As yet, there is no leading workhorse model, one that is ready to be taken to the data, that fully fleshes out the mechanisms through which exposure to competition leads to TFP increases within a plant.

This essay reviews the literature examining the link between competition and productivity that makes progress toward both issues raised above. The papers are mostly industry studies, focusing on particular industries in great detail.

Regarding the first issue - clarity on what is meant by an increase in competition - the bulk of the papers discussed consider industries that have undergone major changes in their competitive environment. In most of the papers, there is little doubt that the industries faced an increase in competition. These papers use direct information on the competitive environment faced by firms, rather than trying to indirectly infer the degree of competition from observations on concentration statistics or price-cost margins, which can be misleading.

The changes in competitive environments discussed below include the Holmes and Schmitz

\footnotetext{
${ }^{1}$ Early on, Stigler (1973) noted that Leibenstein was offering only a definition and not a coherent theory.
} 
(2001) study of how railroad competition influenced water transportation productivity, the Schmitz (2005) study of how competition from Brazilian iron ore influenced U.S. iron ore productivity, the Syverson (2004) study of how market size influences competition and productivity in concrete manufacturing, the Matsa (2009) study of how Wal-Mart's entry into a retail market influenced existing retailer's productivity, the Dunne et al. (2008) study of how foreign competition influenced U.S. cement manufacturing productivity, and the De Loecker (2009) study of liberalization of the Belgian textile trade. In all these studies, and most of the others discussed below, increased competition raised industry productivity.

Consider next the second issue - understanding the mechanisms through which productivity is impacted. In nearly all the studies, increased competition led to productivity gains at surviving plants - what we could call gains in X-efficiency, or what the literature calls within-plant gains. In many of the studies, these X-efficiency or within-plant gains amount to a large fraction of overall industry productivity gains. Hence, we are left with the conundrum above: how do we understand or explain these gains? Many of the papers tackle this issue head-on by asking what changed inside these surviving plants to make their productivity increase? The papers have studied the nitty-gritty of resource allocation within plants. The goal is that by generating a set of facts about how increased exposure to competition impacts resource allocation within plants, we can use these facts to guide further development of theory.

What has been found? In the case of U.S. iron ore, for example, Schmitz (2005) argues that it was investment in new management practices that led to the majority of the productivity gains. He reaches this conclusion, in part, through a detailed analysis of labor contracts specifying what workers were permitted to do, and through an analysis of whether or not machinery was being fully utilized, before and after the threat of Brazilian competition. In the Wal-Mart case, Matsa (2009) argues that existing retailers made new investments in inventory control and the like when Wal-Mart 
showed up in town.

Many of the studies have found, then, that when plants faced increased competition, they made substantial investments to raise productivity. But importantly, note that in most of these changes in the competitive environment, the scale of the plant's market was not increasing but was, if anything, decreasing. So, it was not the possibility of a larger market that drove the increases in investment (the usual scale effect of Arrow).

If not increases in scale, then what drove investment? We'll argue that it was likely that the cost of investment fell as competition increased. To understand this, we use an extended concept of the cost of investment. Typically, the cost of investment or innovation is simply the cost of a new machine, or the cost of the scientists on staff. But there is often an opportunity cost of investment too. Consider the iron ore case. Plant managers understood that attempts to introduce new management practices would likely meet stiff resistance (from unions). So, if they attempted to adopt the practices, strikes were likely, meaning that plants would not produce output for some period of time. Hence, one cost of adoption was the opportunity cost of lost profits during this strike period. This opportunity cost was tied to the price of the product. If the price was very high, the opportunity costs were high. Hence, more competition, meaning lower prices, meant opportunity costs fell, making adoption more likely. Start-up problems can arise in adopting any technology (not just management practices), such as with new inventory control technology in retailing. Holmes et al. (2008) give many real-world cases and label them as "switchover disruptions." With switchover disruptions, and with the possibility that a plant does not produce its entire output for a period of time, one cost of investment is the opportunity cost of lost profits from delayed or lost sales. And competition influences this cost.

In the next section, we present a model that illustrates the two issues highlighted above. First, we discuss the various meanings of an increase in competition in the model. Second, we 
discuss the channels for how a change in competition can impact productivity. We distinguish between channels that are well understood and other channels that are a black box. We also use the model to discuss limitations of reduced-form regression approaches that use concentration measures or price-cost margins as a means of measuring competition. Section 3 discusses industry studies that have examined the impact of competition on productivity. In Section 4, we look at trade liberalization studies. Section 5 concludes.

\section{SIMPLE INDUSTRY MODEL WITH CHANGES IN THE COMPETITIVE ENVIRONMENT}

In this section, we present a simple model of an industry. With the model we illustrate in a more formal way the two issues raised in the introduction. First, we use the model to provide explicit examples of what we mean by changes in the competitive environment. We do this by changing parameters in the model that relate to the extent to which firms have to compete with each other. Second, we use the model to trace channels through which changes in the competitive environment can impact industry productivity.

In the last part of this section, we use the model to comment on empirical approaches based on concentration measures or profit measures, rather than well-defined changes in the competitive environment.

\subsection{Productivity in a Simple Industry Model}

Consider a model of an industry in which there are two locations, $j \in\{1,2\}$. Let $q^{j}=S^{j} d^{j}\left(p^{j}\right)$ be the demand at location $j$ when the price at $j$ is $p^{j}$. The parameter $S^{j}$ scales up demand proportionately, so $d^{j}\left(p^{j}\right)$ can be thought of as per capita demand. Suppose there is a cost to transfer one unit of the industry product between the two locations. The transfer cost is the sum of a physical transportation cost that must be incurred plus a tariff that must be paid on shipments moving from one location 
to the other. Let $T$ denote the transportation cost and $D$ the tariff (or duty). At each location there is a set of potential entrants to the industry. Potential entrants face a fixed cost of entry, which is the sum of a setup cost (e.g., some kind of engineering design expenditures) plus an entry tax. Formally, let $F_{i}^{j}$ and $E_{i}^{j}$ denote the setup cost and entry tax faced by potential entrant $i$ at location $j$. Note that this structure allows for different potential entrants to face different costs. For example, it allows for potential entrant $i$ to be blocked by a prohibitive entry barrier, $E_{i}^{j}=\infty$, while another potential entrant $i^{\prime}$ faces no legal impediments to entry, $E_{i^{\prime}}^{j}=0$. Potential entrants also vary in productivity, conditioned upon entry. Formally, suppose firm $i$ at $j$ produces $y_{i}^{j}=A_{i}^{j} f\left(n_{i}^{j}\right)$ units of output with $n_{i}^{j}$ units of labor. The parameter $A_{i}^{j}$ allows productivity to vary across entering firms. Assume that all firms pay the same wage, normalized to equal one. Finally, suppose entry and production decisions are modeled as a simultaneous-move Cournot game. That is, each firm takes as given the entry and output decisions of all the other firms when making its own decision, and production is allocated across the two locations in a market-clearing fashion.

We will think of changing the competitive environment of the industry by varying the parameters of the model just described. Let a particular competitive environment be indexed by $e$. For a given competitive environment $e$, let $S^{j, e}$ be population at location $j, F_{i}^{j, e}$ the physical cost of entry and $E_{i}^{j, e}$ the entry tax, $T^{e}$ the transportation cost and $D^{e}$ the tariff, and finally $A_{i}^{j, e}$ the productivity parameter of plant $i$ at $j$. (For simplicity, $d^{j}(\cdot)$ and $f(\cdot)$ are held fixed across environments.) Select an equilibrium of the simultaneous-move Cournot game for each environment. We will compare the productivity across the equilibria of different competitive environments. As is well understood, there are potentially multiple equilibria in this class of models. However, this is a side issue that we will ignore to keep the discussion brief. (It can be finessed with comparative statics of sets of equilibria.)

For the equilibrium under competitive environment $e$, let $B^{j, e}$ denote the set of firms that 
actually choose to enter, and let $n_{i}^{j, e}$ and $y_{i}^{j, e}=A_{i}^{j, e} f\left(n_{i}^{j, e}\right)$ denote the equilibrium employment and output of a given entering firm. We can define average productivity in environment $e$ as total industry output across both locations divided by total industry input,

$$
\text { Productivity }^{e}=\frac{\sum_{i \in B^{1, e}} A_{i}^{1, e} f\left(n_{i}^{1, e}\right)+\sum_{i \in B^{2, e}} A_{i}^{2, e} f\left(n_{i}^{2, e}\right)}{\sum_{i \in B^{1, e}}\left(n_{i}^{1, e}+F_{i}^{1, e}\right)+\sum_{i \in B^{2, e}}\left(n_{i}^{2, e}+F_{i}^{2, e}\right)+q_{s h i p}^{e} T^{e}},
$$

where $q_{\text {ship }}^{e}$ is the total volume of shipments between locations in environment $e$ that incurs the transportation cost $T^{e}$. We include as inputs labor, setup costs, and transportation costs, but not entry taxes or tariffs.

In comparing industry productivity across competitive environments, separating out three sources of productivity differences is useful. The first source of change is often called the reallocation source in the literature, beginning with Bailey et al. (1992). In particular, suppose that on account of a change in the competitive environment, a firm with low productivity parameter $A$ is replaced by one with a high productivity parameter. Everything else the same, this will tend to raise overall industry productivity. For example, Hsieh \& Klenow (2007) show that part of the reason TFP is higher in the United States compared to China is that the U.S. economy does a better job of allocating production to plants with high $A$ compared to China.

The second source of change is the scale effect. For simplicity, suppose all firms have the same marginal cost and the same fixed cost of entry. If, on account of a change in the competitive environment, one firm produces the same amount as two firms previously, everything else the same, industry productivity increases. That's because one fixed cost expenditure replaces two fixed cost expenditures in the denominator of (1). It is well understood that with free entry (no entry taxes), plants might be inefficiently small, relative to the degree of scale economies. Mankiw \& Whinston (1986) is the standard reference for "excess entry" in the above model (in which too many firms enter and carve up a fixed market too many ways). The scale effect also shows up in the famous Arrow (1962) paper on the incentive to innovate, which showed that a firm with a larger market 
size is more likely to pay a fixed cost to lower marginal cost.

The third source of change is the X-efficiency or within-firm effect. A change in the competitive environment might change the productivity parameter $A$ or the fixed cost (and is unrelated to a change in the ability of the firm to enjoy scale economies). That is, for two different environments, $e$ and $e^{\prime}$, we may have $A_{i}^{j, e} \neq A_{i}^{j, e^{\prime}}$ or $F_{i}^{j, e} \neq F_{i}^{j, e^{\prime}}$ or both. Although the two other sources of productivity change can be explicitly modeled, this X-efficiency change is a so-called black box. One of the primary goals of the papers discussed below is to delve into this black box to determine the sources of the within-firm effect.

\subsection{Some Changes in the Competitive Environment}

Now we go through examples of changes that make the environment more competitive. Let $e=m$ indicate the initial regime (where $m$ indicates that this regime is more monopolistic) and $e=c$ indicate the new regime (where $c$ indicates that this regime is more competitive).

\section{Entry Restrictions}

First consider government-imposed entry restrictions. Suppose that in the initial regime, there is no restriction on firms at location 1 from entering the industry, but entry is blocked to firms at location 2. (This is equivalent to setting the entry tax at location 1 to $E_{i}^{1, m}=0$, and at location 2 to $E_{i}^{2, m}=\infty$ for every firm $i$.) In the initial equilibrium with this restriction, suppose that a large number of "small" firms enter at location 1. In the new environment after the restriction is lifted (i.e., $\left.E_{i}^{2, c}=0\right)$, suppose one extremely productive firm enters at location 2 that supplies most of the industry output, displacing most of the small firms at location $1 .^{2}$ This is the situation described in the introduction.

This change in the competitive environment will certainly lead to a change in industry pro-

\footnotetext{
${ }^{2}$ We could think of $T=0$, so that there really is no "location," and that inefficient firms at location 1 were able to construct an entry barrier to a very efficient firm.
} 
ductivity through the reallocation component. It possibly may change industry productivity through the scale effect. And the within-firm channel might come into play as well. Facing competition from the new large firm at location 2, the small firms at location 1 might respond, and the parameters for

these firms might change, i.e., $A_{i}^{1, m} \neq A_{i}^{1, c}$ or $F_{i}^{1, m} \neq F_{i}^{2, m}$ or both. (See our discussion of Matsa 2009 below.)

This change in the competitive environment - elimination of an entry restriction - can best be thought of as an experiment that increases competition. But note that in the new regime, concentration (as measured by the Herfindahl index, for example) will actually be higher and, potentially, profits as well. We will return to this example below when we discuss approaches that measure changes in competition through changes in concentration and profit margins rather than underlying environment changes.

\section{Technological Change}

Obviously, technological change can directly increase industry productivity. But here, our focus is on how technological change can indirectly change industry productivity, through a change in the competitive environment.

In particular, in the example above, we can reinterpret the fall in the entry barrier as something that occurs through a technological advance rather than a change in policy. That is, we can interpret the real resource cost of entry as falling from infinity to zero (instead of the entry tax falling from infinity to zero). Thus, there is no change in the discussion of how industry productivity can be impacted. Later when we discuss the impact of the advent of railroads in the 19th century on water transportation productivity (Holmes \& Schmitz 2001), this is the model that we will have in mind. 


\section{Tariff and Transport Cost Reductions}

Next consider a change where either the transportation cost or the tariff duty is reduced in a significant way, so the cost of shipping goods between the locations declines, $T^{m}+D^{m}>T^{c}+D^{c}$.

Suppose that in the equilibrium of the initial, high transfer cost environment, there are a large number of small firms at location 1 with low values of $A_{i}^{1}$. And suppose there is one large efficient firm at location 2 with high $A_{i}^{2}$. The small firms at location 1 are initially protected from the big efficient firm at location 2 because of the transfer cost barrier. After the significant decline in transfer costs, the small, inefficient firms at location 1 are no longer protected.

Like the example where entry restrictions were eliminated, the efficient firm at location 2 might displace the inefficient firms at 1 , raising industry productivity through reallocation. There might also be scale effects. And, as discussed in the previous example, there might be within-firm improvements in productivity, i.e., $A_{i}^{1, m}<A_{i}^{1, c}$, as the firms respond to the increase in competition.

One point worth making is that the within-firm responses, $A_{i}^{1, m}<A_{i}^{1, c}$, might in principle be of sufficient magnitude that the firms at location 1 retain their market share, so in the end, firm 2 makes no shipments to location 1 . In this case, the change in competitive pressure at location 1 from potential imports from location 2 is responsible for inducing changes in productivity. Yet there is no difference in the measured volume of imports. This is analogous to how in Holmes \& Schmitz (1995), a reduction in tariffs leads to increases in productivity, even though there are no international trade shipments in equilibrium after the tariff reduction. It is also basically what happened when Brazil threatened U.S. iron ore producers (Schmitz 2005).

\section{Changes in Market Size}

Next consider changes in market size, in particular changes in the market scaling parameters so that $S^{1, m}<S^{1, c}$ and $S^{2, m}<S^{2, c}$. An increase in market size impacts the competitive environment because, given the existence of entry costs, in larger markets there is greater equilibrium entry (as 
in the Sutton 2007 "exogenous fixed cost" case).

Beginning with Bresnahan \& Reiss (1991), there is an extensive literature examining how changes in market size impact pricing and entry behavior. (For a more recent strand of this literature, see Pakes et al. 2007.) Since a central focus of this literature is the estimation of fixed costs of entry and entry policy rules, these models can be used to evaluate how changes in market size can impact industry productivity through the scale effect discussed above. In contrast, the within-firm channel discussed above, and how that might be impacted from the increased competition of larger markets, has not been a focus of this literature.

Syverson (2004) is a leading example of a recent paper analyzing productivity using changes in market size. This paper can be interpreted as focusing on the reallocation source discussed above. As discussed below, in large markets, production is reallocated from inefficient plants to efficient plants, but in small markets this doesn't necessarily happen.

\subsection{Approaches Based on Concentration or Profits}

The above discussion lists a variety of ways in which the underlying environment in an industry can become more competitive. The empirical studies we discuss starting in Section 3 involve a change in the competitive environment that can be found somewhere on the list above (or are a modification of something on the list). The studies are very clear about the nature of the environmental change and explicitly document it.

There exists an alternative approach that looks at changes in concentration or changes in price-cost margins, rather than changes in the underlying competitive environment. In particular, lower industry concentration and lower price-cost margins are regarded as proxying more competition, and these are compared with statistics on productivity. We believe this approach has two serious drawbacks.

First, even if changes in concentration or profit margins over time are being driven by changes 
in the underlying competitive environment, it is not necessarily the case that these measures will go in the right direction. To be more clear about this, suppose the underlying data generation process consists of repeated observations of the model described above, across different industry observations that are different draws for the entry tax, i.e., different barriers to entry. An approach that associates lower concentration and lower profit margins with a more competitive environment might get things right sometimes. But it won't other times. To make the point for concentration, recall the example above where a decrease in entry barriers led to an increase in concentration (note that this is not classical measurement error). To make the point for profit margins, note that in many cases, monopoly rents get captured by employees of firms rather than shareholders. If entry barriers are reduced, this might lead to lower rents for employees instead of lower profits. (See Salinger 1984 for a discussion of this point.)

Second, measures of concentration and profit can change over time for reasons unrelated to changes in the competitive environment. Again, take repeated observations of the above model as the data-generating process, but now keep the competitive environment fixed across observations, e.g., let there be no differences in entry taxes across observations. But do allow for different draws of the vectors of $A_{i}^{j}$ parameters across observations. Let's say that for one draw, i.e., a particular industry observation, firms are all similar in having a mediocre level of productivity $A_{i}^{j}$. These firms share the market equally, and there is not much in the way of rents (or profits) given that the firms are all similar in productivity. Now suppose for another industry observation, everything is the same except there is also a firm in the industry with a huge $A_{i}^{j}$ draw relative to all the mediocre firms. It follows that in this second industry there will be a huge firm with huge profits, making the industry highly concentrated and highly profitable. But all of this is happening with no change in the competitive environment.

This second point is the famous criticism made by Demsetz (1973) almost 40 years ago about 
the interpretation of regressions of industry profit on industry concentration. He was criticizing the structure/conduct/performance literature initiated by Bain (1951). When Demsetz was making his point, he was referring to a cross section of different industries. But his point is equally valid for looking within an industry over time. That is, it doesn't help matters to get a panel of industries and throw in industry fixed effects. Concentration can increase over time within an industry for the same Demsetz reason that concentration can vary across industries.

Moreover, if we look at industry profit margins, there are numerous additional kinds of shocks that lead to fluctuations over time in profit within an industry that are unrelated to changes in the underlying competitive environment. For example, Lambson (1992) shows how shocks to demand, technology, and input prices can lead to short-run fluctuations in the return to industry-specific capital.

A well-known paper that uses concentration and profits to measure competition is Nickell (1996). Although this paper updates Bain, on the whole it is a direct descendent of Bain. One update is the use of firm-level panel data instead of an industry cross section. The main regression is of firm-level productivity on industry variables like industry concentration, on a firm fixed effect, and on a firm's own market share in a period. The paper interprets a firm's own market share as some kind of inverse measure of the competitive environment faced by the firm. The arguments made above about the usefulness of industry-level measures of concentration apply equally well at the firm level. To take an example from above, a reduction in a tariff may in the end have no impact on a firm's market share but may still have a huge impact in changing the competitive environment.

A well-known recent paper that relates innovative activity to industry-level price-cost margins is Aghion et al (2005). Using data from the United Kingdom, the paper estimates a relationship using fixed industry and time effects. What distinguishes its approach from the earlier Bain tradition is the use of instruments to control for the endogeneity of profit margins. Specifically, the paper 
uses as instruments the timing of various policy changes, such as privatizations taking place under Margaret Thatcher, antitrust actions, and trade policies. These policies are all interesting and likely do impact the competitive environment. However, in the paper, all of the individual effects of these policies are buried under the hood in a first stage estimate, with all effects in the end forced to run through the price-cost margin. Our concern about the use of the price-cost margin goes beyond the paper's concern that it is endogenous; we are worried that changes in the variable don't satisfactorily correspond to changes in competition. For example, there is evidence that the privatizations in the UK led to transfers of monopoly rents away from workers. (These took place in the form of greater effort per worker through employment cuts rather than wage cuts; see Haskel \& Szymanski 1993 and Haskel \& Sanchis 1995.) So, price-cost margins may not have changed, or may have even gone up, as a result of the privatizations.

\section{STUDIES OF INDUSTRIES FACING COMPETITION}

In this section, we'll review a series of papers that have examined industries which underwent changes in their competitive environment, like those discussed in the theory section above, where there is little doubt that competition increased.

\subsection{The Coming of Railroads and Productivity in Long-Distance Water Shipping}

Here we discuss competition in an industry from the development of a new, competing technology. Holmes \& Schmitz (2001) examine the impact on freight transportation by water (water shipping for short) from the development of railroads. They discuss evidence from both the 19th and 20th centuries and document that railroads increased the competition faced by water shipping, and that this led to significant productivity improvements in water transportation.

We first argue that there was a strong tendency for monopoly or market power to develop in water shipping, and that railroads broke up some of this market power. Then we turn to productivity. 
We start with a historical example. Imagine a farmer, say, in 1850, wishing to transport bales of cotton from the U.S. South, say, very close to the Mississippi River in Louisiana, to the U.S. Northeast. Trains had not come to the South. The most natural way to make the shipment would be a short wagon ride to the Mississippi River, then down the river to New Orleans, and then on to the Northeast over water. Few other options were available. One could ship up the Mississippi River, then the Ohio River, then an Ohio canal, and then the Erie Canal, and so on. Another option would be to use other ports in the Gulf of Mexico, though this would entail shipping the bales by wagon to other more distant rivers. Given that these other options were so expensive, having a monopoly on traffic coming through the port of New Orleans would be very lucrative. The incentives to create a monopoly were great, and monopolies were created in the port.

One such monopoly was on supplying labor in the port of New Orleans. As early as the 1850s, there were strong unions of dockworkers in New Orleans. Holmes and Schmitz document the very high wages and entry fees to join the unions. It was also claimed that price gouging took place in warehouses. ${ }^{3}$

Consider what the advent of railroads meant. With railroads, it was much easier for farmers to use other ports in the Gulf. Shipments by land to other rivers were now much cheaper (rail was much cheaper than wagon). And, of course, shipping directly over land to the Northeast, and bypassing water altogether, was now an economic possibility. Railroads, then, provided a significant threat to the monopolies created in the port of New Orleans. And the threat weakened the market power of groups like unions in the New Orleans port. Moreover, one sees that railroads broke up monopolies in ports throughout the 19th and 20th centuries by offering shippers an opportunity to use other ports or to bypass water altogether.

Now let's turn to the impact of railroad competition on productivity in the ports. Before

\footnotetext{
${ }^{3}$ In the late 19th century, business leaders in New Orleans decried the high prices charged by warehouse owners and claimed that the prices were diverting cargo to railroads and other ports (see, e.g., Hester 1896).
} 
that, a brief digression is in order. As part of the deals struck by unions in ports, work rules often required that machinery could not be used in loading or unloading ships, or only in limited ways. Holmes and Schmitz give examples in New Orleans in the 19th century. Another type of work rule in ports in the 19th and 20th centuries concerned multiple handling of cargo. When longshoremen removed a pallet from the deck of a boat and moved it to the dock, a rule required that longshoremen unload the pallet on the dock. Only then could a trucker reload the cargo onto his pallet. The same rules held for loading material onto boats. The trucker would have to put cargo on the dock to then be loaded by longshoremen onto their pallets. Pallets could not go from the truck to the boat (see, e.g., Kossoris 1961 and Killingsworth 1962).

These types of work rules obviously lowered labor productivity. One could claim that they increased leisure too. But a key point is that the rules reduced capital productivity. Unloading and loading boats took much longer because of the rules. Hence, boats stayed in port much longer than necessary.

Now back to the railroads' impact on productivity. Railroads not only led to lower wages in ports but also led to the dropping of many of these restrictive work practices; that is, they increased productivity. The historical record makes it clear that longshoremen decided to respond to railroad competition and did so by dropping work rules, such as the multiple handling of cargo. In discussing U.S. West Coast longshore rules in the 1930s to 1960s, and how they were made looser in the 1960s, Killingsworth and Kossoris cite railroad competition on intercoastal traffic as a major reason why new, less restrictive labor agreements could be reached. It's interesting to note that in negotiations about how much longshoremen should be compensated to drop some work rules, the union demanded part of the gains that came from ships being able to leave ports more quickly than before.

As additional evidence that longshoremen responded to rail competition by increasing pro- 
ductivity, it was often the case that longshoremen had different rules for working ships that went between ports that could be serviced by railroads (say, Los Angeles to Seattle) and those that could not (say, Los Angeles to Hong Kong). Work rules were relaxed on those ships that competed with trains. Hence, these ships spent less time in port.

Finally, a historical note. In his famous analysis of the contribution of railroads to economic growth, Fogel $(1964,1979)$ assumed that railroad competition had no impact on the prices or productivity in water shipping. This was an important assumption in his estimation of railroads' benefits to growth. This assumption was not even approximately correct: railroads had very large impact on both prices and productivity in 19th (and 20th) century water shipping. ${ }^{4}$

\subsection{When the Brazilians Nearly Came: Productivity in U.S. Iron Ore Manufacturing}

Here we look at competition in an industry when a new competitor shows up, in part because of lower transportation costs. In the early 1980s, Brazilian iron ore producers showed up to compete with U.S. iron ore manufacturers for the market around the lower Great Lakes (around Chicago and Cleveland). This was a huge surge in competition for U.S. iron ore producers (who were located in Minnesota and Michigan) (see Galdon-Sanchez \& Schmitz 2002 and Schmitz 2005). U.S. productivity surged with the advent of competition.

We first argue that there was a strong tendency for monopoly in iron ore manufacturing and that Brazil broke it up. Then we turn to productivity.

The tendency for market power in iron ore manufacturing comes from the fact that iron ore can be produced at only a few locations and that transport costs are large. For example, imagine iron ore deposits located near some steel mills. And suppose the next closest deposits of iron ore are very far away. Suppose demand for iron ore at the local steel mills is inelastic. A quantity $Q$ will

\footnotetext{
${ }^{4}$ Water shipping, of course, impacted prices and technology in railroads too. And when trucks were developed, it impacted technology in both water and rail shipping (as they influenced it). Cappelli (1990) gives interesting examples of unions in the railroad industry that agreed to have different (more flexible) work rules on trains that competed with trucks than on trains that did not compete with trucks (e.g., trains carrying coal).
} 
be demanded at a price of $\bar{p}$ or less and zero otherwise. Let $c$ be the local production costs of iron ore. To keep things simple, suppose iron ore is free at the distant location but costs $t$ to transport to the local steel mills. Suppose $t>c$.

If the local deposits are owned by a large number of producers (i.e., there are a large number of independent mines), then price competition will mean the local ore will sell for $p_{L}=c$ ( $L$ indicates local iron ore). But if somehow the price could be raised to $t$ (assuming $\bar{p}>t$ ), there would be a profit $(t-c)$ per unit. So, if some type of monopoly can be arranged, it may well be lucrative.

This is a reasonable abstraction for thinking about the U.S. iron ore industry. Its deposits were located primarily in Minnesota. These were fairly close to the large steel mills in the lower Great Lakes (around Chicago and Cleveland). The cost of transportation from the next closest major deposits (in Brazil) to Chicago was much higher than the transport costs for U.S. producers. ${ }^{5}$

As we said, if monopolies could be arranged they might be lucrative, and they were indeed arranged. Many groups (i.e., input suppliers) in the state of Minnesota recognized the logic of market power sketched above. Many groups organized to capture some of the returns to this market power. First, governments at many levels (such as the state, county, township, and school board) charged the mines very high taxes on each ton of iron ore produced. Second, a powerful union charged high prices for labor. We can think of all these groups as adding to the costs of iron ore, of adding to $c$, and pushing the price of iron ore toward $p_{L}=t$.

In the early 1980s, Brazil broke up much of the market power in U.S. iron ore production. At this time, Brazil offered to sell iron ore in Chicago at prices well below the price of Minnesota iron ore. Brazil was a huge competitive threat. What changed to make it a threat? There were significant reductions in transport costs in the 1980s. Another reason was that Brazil lost markets

\footnotetext{
${ }^{5}$ There were, in fact, major deposits of iron ore in eastern Canada, close (relative to Brazil) to U.S. deposits. But there was a common union across the U.S. and Canadian mines, the United Steelworkers of America. This union was a monopoly supplier of labor to the mines in the whole region.
} 
elsewhere. ${ }^{6}$

Turning to productivity, there was little labor productivity growth in Minnesota iron ore before the 1980s, and then it surged with Brazilian competition. Labor productivity doubled in a few years in the mid-1980s. Though there is no published industry TFP measure in the United States, Schmitz makes arguments that it too increased a lot. ${ }^{7}$

What were the sources of these industry productivity gains in the 1980s? Recall our taxonomy regarding sources of gains. First, competition could have closed inefficient mines. In fact, some Minnesota mines were closed, yet their productivity was about the same as the industry average. A formal labor productivity growth decomposition shows that over the decade 1980-90, when industry labor productivity doubled, closing plants accounted for none of the productivity increase.

Second, competition could have changed the scale of the mines, to scales with higher productivity. In fact, the scale of mines that remained opened did not change much.

Third, the competition could have led to increases in productivity at the continuing plants. In the productivity growth decomposition above, productivity gains within continuing plants accounted for the vast majority of the 1980-90 gains (95 percent of the gains).

What are we to make of this last result? Note that in the mines that remained open, productivity was flat in the period before the crisis and soared afterward. We might be tempted to say, then, that the increase in competition led to changes inside the plants that increased productivity. But let's play devil's advocate here. Competition meant that some mines closed. So, maybe we are just seeing the mines that had the best prospects for the future (including the best productivity growth prospects). This is a different type of selection than above, when we asked if the 1980-90

\footnotetext{
${ }^{6}$ Still another reason is that (see below) U.S. productivity had not been increasing for years, while Brazil's productivity was.

${ }^{7}$ As mentioned in the note above, Canada's iron ore industry had the same union as the U.S. industry. The labor productivity record in Canada looks nearly identical to that in the United States. For Canada, there is an industry TFP series, and it also grows dramatically in the 1980 s.
} 
productivity growth was driven by closing mines that had low levels of productivity in 1980. This is a selection on expected growth over 1980-90.

How can we prove, then, that competition was responsible for the significant productivity growth in continuing mines, and not some selection process? One way to proceed is to go inside the plants, so to speak, and find out what actually drove the productivity gains. And then we ask, was it competition that drove these changes? Schmitz (2005) identifies the changes (some of which are given below) and argues that they were likely due to Brazilian competition.

What were some of these changes? Let us give some examples; more are in Schmitz (2005). These mines ran 24 hours a day, so there were three shift changes. They were huge open pit mines, many square miles around, and each shift change required that men working on the trucks and blasting equipment throughout the mines had to be picked up and replaced with new men. During the crisis in the mid-1980s, the companies sought to change the rules on these shift changes, seeking to establish "eyeball-to-eyeball" crew relief. Before the crisis, small vans would drive around the mine picking up the men at the end of their shift. These men would be returned to a central location. Next, the vans would take out the men for the new shift. Hence, all the equipment would be idle for a not insignificant portion of the shift. The companies asked the union to go to eyeball-to-eyeball crew relief, so that the new men would be in the vans when the old shift men left their equipment. The term comes from the fact that they would pass each other eyeball-to-eyeball.

The union resisted the change, and the company brought it to arbitration. The arbitrator said that output would be larger with eyeball-to-eyeball crew relief and ruled for the companies. This change led to increases in TFP; all productivities were increased.

Another type of work rule was repair-job classifications. Before the crisis, repair staff were assigned a certain classification (such as welder, pipefitter, and so on, amounting to 30 or more classifications). Workers in a classification could only do certain repair jobs. Suppose a machine 
became jammed and inoperable. First, the machine operator was precluded from repairing it. And only repair workers assigned to fixing this part of the machine could repair it (moreover, the operator could not help). Even if this was a simple job that other repair staff could accomplish, they were not allowed. This, of course, meant larger repair staffs than needed. But it also meant that broken machines were down much longer than necessary. The rules reduced capital productivity and energy productivity (in these mines, energy is always "on").

During the crisis, the union agreed to change many repair work practices. First, machine operators were now permitted to conduct minor repairs on their machines. Second, repair workers were allowed to conduct a broader range of jobs. The impacts on repair staffs were dramatic. Whereas before the crisis, repair staffs amounted to about 50 percent of the total workforce at mines, after the rule changes repair staffs fell to about 25 percent of the workforce. And this was at a time when total workforces were falling by half!

With these changes in work practices, productivity surged in Minnesota mines. As a result, the Brazilian competition was met head on, and the Brazilians did not take over the lower Great Lakes market.

The above discussion illustrates that in the 1980s, in the face of competition and (potentially) shrinking markets, the industry made investments (in new management practices) to increase productivity. The earlier history of the industry, as we'll now discuss, also illustrates that firms with (potential) market power may be wary of investing.

In Minnesota, in the 1910s and 1920s, it was clear that the local natural iron ore deposits would be depleted before too long. What would remain was a hard rock called taconite (which contained a low percentage of iron). An engineer at the University of Minnesota, Ed Davis, developed a technology to make the taconite into high-grade iron ore pellets. The technology required major investments. In the 1930s, Davis presented U.S. steel company executives with the results of decades- 
long research into making pellets. It was clear that whatever company built the infrastructure to make this new iron ore would have great market power, since the closest competing iron ore was thousands of miles away (from Chicago-area steel plants). But the U.S. steel executives balked at making the investments. They were worried about being taxed and so forth. Davis then went to the Department of Economics and the Law School at the University of Minnesota, and with their help drafted (and passed, in 1941) a new law that limited taxation on taconite. ${ }^{8}$ The steel executives were satisfied that the law put enough constraints on taxation, and the taconite pellet industry was developed in the 1950s. This was the industry threatened by the Brazilians in the 1980s.

This episode illustrates that if a firm has (potential) market power, it may be wary of investing in new technology. If a firm has no competitors, and if input suppliers to the firm can establish their own market power, they can then extract the surplus from the firm's innovation (since in raising input charges, there is no fear that competitors will capture the market). Given this incentive, suppliers will endeavor to do so. This is opposite the idea, attributed to Schumpeter, that market power is needed for investment. Although agreements can be reached (such as the new tax laws above) to limit these problems, often they are not, and even when they are reached, they are often not that effective. In fact, we see that some of the fears of the U.S. steel executives came to pass, as the towns and unions extracted so much surplus that Brazilian iron ore became competitive in Chicago.

\subsection{Markets of Different Sizes and Concrete Manufacturing Productivity}

Here we look at how competition varies across markets in concrete manufacturing. Concrete is shipped only very short distances. Hence, the scale of production is often large relative to market size. In rural areas and small cities, there may be room in the market for only one or two producers.

\footnotetext{
${ }^{8}$ Davis (1964) discusses in detail the efforts to convince steel executives that the law was not "a 'come on' to get taconite plants built, after which the tax base would be increased" (p. 99).
} 
In large urban areas there is likely room for a much larger number of producers. Producers in larger markets then face more competition than producers in small markets.

In an interesting paper, Syverson (2004) develops this idea and determines how market size (and therefore competition) impacts the distribution of productivities. The paper shows that plants tend to be more productive in larger markets because the bottom tail of low productivity plants tends to be weeded out in larger markets. The interpretation is that low productivity plants can not survive in larger markets because they would have to compete with the very high productivity plants that can typically be found in such places. We expect high productivity plants in large markets because with so many random entry draws in large markets, at least some will turn out to be high productivity. In contrast, small markets may have no very high productivity plants, and so a low productivity plant can survive (see also Collard-Wexler 2010).

\subsection{When Wal-Mart Came to Town}

In U.S. retail markets, the entry of Wal-Mart provided a significant increase in competition to existing retailers. Matsa (2009) finds that after Wal-Mart's entry, existing firms improve their productivity. In particular, Matsa looks at the impact of competition on supermarkets' provision of quality, measured by product availability. He shows that competition from Wal-Mart led competing supermarkets to reduce stockouts (when products become unavailable to shoppers) by up to 24 percent. He concludes that the reductions in stockouts were brought about by new investments (e.g., in computers tracking inventories), and not through changes in product mix (across products with different stockout rates). As in the iron ore case, in the face of (likely) shrinking markets (since Wal-Mart was not leaving), firms made investments to increase productivity. 


\subsection{When Almost Everyone Came: Productivity in U.S. Cement Manufacturing}

U.S. cement producers faced a dramatic increase in competition in the middle 1980s (see Dunne et al. 2008). This industry had faced little foreign competition for decades. Then, in the 1980s, many countries (e.g., Australia, Japan, Mexico, Spain, Greece, Venezuela, and others) offered to sell cement at steep discounts to U.S. cement producers, and many did. The increase in competition was due in part to improvements in the technology to transport cement over water. But the primary factor was likely that U.S. cement industry TFP had been falling for decades, while it had been increasing around the world. In response to the competition, cement plants made investments that led to a doubling of labor productivity, and a huge increase in TFP, in a few years.

We first argue that there was a strong tendency toward monopoly in cement manufacturing and that foreign competition broke it up. Then we turn to productivity.

Though cement is shipped at farther distances than concrete, it is still shipped at fairly short distances over land (the majority is shipped within a couple of hundred miles of the plant). Hence, in some markets, the efficient scale of production is fairly big relative to the local market size. There might be only one or two plants supplying a local market. Hence, there is a tendency for market power. And, in any case, a strong national union developed in the late 1950s and 1960s that acted as a monopolist in supplying labor to the industry.

This market power was exploited by various groups in the industry. As in iron ore manufacturing, U.S. states (such as Texas) taxed the quantity of cement produced. The union also charged very high wages. Wages were comparable to those of U.S. autoworkers (see Northrup 1989).

In the middle 1980s, foreign cement producers broke up much of this market power. Before the 1970s, there were virtually no imports into the United States. Then, in the 1980s, imports surged, reaching about 30 percent of production in many years. These imports broke up much of the monopoly in U.S. cement manufacturing. The union, in fact, disintegrated in 1984 (again, see 
Northrup 1989). What changed in the 1980s? There were improvements in transportation. But probably more important, U.S. producers had become less productive than most producers in the world, as we now describe.

Turning our discussion to productivity, industry TFP was falling, by roughly 10 percent, in the United States in the two decades before the increase in imports. ${ }^{9}$ In the decade after imports surged, industry TFP increased by about 35 percent.

What were the sources of these industry productivity gains in the 1980s? Consider labor productivity. Over the period 1982-87, industry labor productivity grew roughly 40 percent. In a formal labor productivity growth decomposition, productivity gains within continuing plants accounted for a significant majority of the 1982-87 gains (roughly 75 percent of the gains). Given that there are only a small number of plants in the industry — on the order of 125 to 150 plants - we cannot, for disclosure concerns, report the gains due to closing plants. But we can say, of course, that it cannot be bigger than 25 percent of the gains, since the within-plant term is 75 percent.

A significant share of the industry productivity gain is, then, within-plant gains. Again, we might be tempted to say that the increase in competition led to changes inside the plants that increased productivity. But, as above, perhaps the phenomenal within-plant growth is driven by selection, and that we are just seeing the plants that had the best prospects for the future (including the best productivity growth prospects). Again, one way to proceed is to go inside the plants and find out what actually drove the productivity gains. Dunne et al. (2008) identify significant changes in these plants that increased productivity (some of which are given below), and argue that they were likely due to competition.

What were some of these changes? Let us give some examples; more are in Dunne et al. (2008). Before the crisis, firms were not able to terminate an employee because the firm purchased

\footnotetext{
${ }^{9}$ In contrast, productivity had been growing significantly in most countries.
} 
a new machine, figured out a way to better organize work, and so on. ${ }^{10}$ With the import surge, this restriction was dropped, and plants could fire redundant workers.

Before the crisis, the rights to repair jobs at the plants were divided among departments. ${ }^{11}$ Hence, if a particular repair job was needed, and that department was busy, the repair job had to wait. Broken machines were down much longer than necessary. The rules reduced capital productivity and energy productivity (in these plants, energy is always "on"). These restrictions were also dropped.

As in the iron ore and Wal-Mart cases, the cement industry, in the face of competition that shrank markets, made investments (here, in new management practices) to increase productivity.

The history also illustrates that market power can reduce innovation. Recall the contract clause that forbade plants to fire workers because the plant bought a new machine or figured out a better way to organize production. This clause was introduced into contracts only after the union had built enough power to force its inclusion (in 1965). Again, the clause, everything else equal, limited innovation and investment in the industry. But note that the union would not have pushed for its inclusion if there had not been market power in the industry. If foreign competition had been a threat, then there would be no sense in slowing industry innovation.

\subsection{When Belgium Liberalized Textiles}

When a country liberalizes its trade regime by reducing tariffs on imports, this clearly increases competitive pressure on domestic firms, as in the model above if tariffs are reduced. De Loecker (2009) studies the impact on productivity on Belgian textile manufacturing of reductions in import

\footnotetext{
${ }^{10}$ For example, the following clause appeared in nearly all cement contracts before the crisis: "Employees will not be terminated by the Company as the result of mechanization, automation, change in production methods, the installation of new or larger equipment, the combining or the elimination of jobs."

${ }^{11}$ For example, one finds clauses like these: "[W]hen the Finish Grind Department is completely down for repairs, the Company will not use Repairmen assigned to the Clinker Handling Department on repairs in the Finish Grind Department" and "Repair work on internal combustion engines will be performed by the Materials Handling Department except for minor repairs or adjustments."
} 
quotas on textile products. He finds that industry productivity increases following the liberalization. One concern, of course, is that the mix of textile products in Belgium changed as quotas were lifted, and that this changing mix might explain the measured productivity increase. By using very detailed data on textile products, De Loecker argues that productivity did in fact increase in the industry, though by less than would be estimated if one ignored the changes in product mix (see further discussion below).

\subsection{When the U.S. Government Closed a Cartel}

In this section, we look at the impact of an increase in competition resulting from the U.S. government closing a cartel. We'll show that there was a large increase in productivity, and that a good part of the increase was from the shutting down of inefficient producers and the entry of more efficient ones (see Bridgman et al. 2009).

During the Depression, the U.S. government allowed industries to cartelize. One industry that cartelized was the U.S. sugar manufacturing industry. Although most cartels lasted only a few years (because the Supreme Court ruled them unconstitutional), the sugar cartel lasted 40 years, from 1934 to 1974. In 1974, with a surge in world sugar prices, the cartel lost its support and was ended.

The cartel agreement called for no new firms to enter the industry and gave existing firms production quotas each year. These provisions alone did not protect incumbent farmers. For example, if a firm chose to relocate its production quota from one region to another, this would obviously hurt incumbent farmers (those in the initial region). Hence, the cartel agreement also prohibited the entry of new farmers. The result of this agreement was to lock in patterns of regional production.

Over the period 1934-74, there were forces making the far West a less attractive, and the Midwest a more attractive, location to manufacture sugar. For example, the price of land in the 
West rose faster than that in the Midwest. Hence, once the cartel was ended and the provisions locking in regional patterns of production eliminated, there was a very large change in the regional pattern of production. Production in the U.S. far West, including California, declined dramatically. Production in the Midwest, including North Dakota and Minnesota, soared. Here, the source of the gain in productivity was closing inefficient producers (really, entire regions) and entry of new producers.

\subsection{Did ADM Spur Intel to Innovate?}

Thus far, we have looked at industries that have faced a dramatic increase in competition as a result of some event, such as Wal-Mart coming to town. Another important way to learn about the impact of competition is to run experiments in models. There is now an emerging literature doing just this.

Goettler \& Gordon (2009) examine the PC microprocessor industry, where Intel and ADM make up the vast majority of the market. They ask whether Intel (which is much larger than $\mathrm{ADM}$ ) was pushed to innovate by having $\mathrm{ADM}$ as a competitor. They estimate a model of industry innovation, using the paths of prices, innovation, and so on, that were observed with both firms in the market. They then run sensible experiments, such as asking what would happen to Intel's rate of innovation if $\mathrm{ADM}$ were precluded from the market. In their model, an Intel monopoly would have led to more innovation than the actual duopoly. Hence, here as opposed to most of the studies we have seen, competition leads to less investment. ${ }^{12}$

Other studies following a similar approach are those by Copeland \& Shapiro (2010) on technology adoption in personal computers, Macieira (2009) on competition in the supercomputer industry, and $\mathrm{Xu}(2008)$ on the Korean electric motor manufacturing.

\footnotetext{
${ }^{12}$ Note that in the model, the research productivity of Intel does not depend on whether ADM is in the market or not. There is no idea that a monopolist might become inefficient. Of course, as we suggested above, there is no simple or generally accepted way to include this possibility in a model. We mention this only because it may actually be important (and something to consider later).
} 


\section{STUDIES LOOKING AT TRADE LIBERALIZATIONS AND COMMON}

\section{MARKETS}

In the last decade or so, there has been a surge in papers studying the impacts on industry productivity of trade liberalizations and market openings. What distinguishes the studies discussed in this section (from those above) is that they typically examine a large number of industries simultaneously and do not (for obvious reasons) examine details of industries.

For our purposes, we divide the studies into two groups. We first discuss studies of unilateral tariff reductions, whereby a country reduces its tariffs against the world (while the tariffs it faces are unchanged). In this case, it is likely that the potential market for any plant is shrinking (or not increasing). In this sense, the situation such a plant faces is like that of plants in the iron ore, Wal-Mart, and cement studies above.

We then briefly discuss studies of liberalizations whereby all countries reduce tariffs together, as when common markets are formed. In this case, the potential market for most plants is likely increasing.

\subsection{Trade Liberalization}

There is a large, recent literature that studies unilateral tariff reductions. One strength of this literature is that, in general, it has examined instances of significant liberalization. It is easier to determine the impact of competition when changes are big and are not overwhelmed by other noise. A second strength of the literature is that much is based on census micro data where productivity can be calculated at the plant level. The literature has typically found that industries facing the greatest reduction in tariffs (or the greatest openness to trade when tariffs fell) have faster productivity growth than industries facing the least reduction in tariffs. This arises both through reallocation (exit of inefficient plants) and through productivity increases within existing plants. So, like the studies of specific industries in the section above, these papers find within-plant productivity gains 
even as markets shrink.

One of the earliest studies of unilateral tariff reductions was that by Tybout et al. (1991), which focused on the impact of the significant trade liberalization in Chile in the late 1970s. Pavcnik (2002) also studied this case. Pavcnik distinguished between those industries that tended to be nontraded (initially having low imports and exports) from industries that were import competing (initially having some imports). Pavcnik showed that over the liberalization period, industry-level productivity of the import-competing industries grew relative to the nontraded industry on the order of 25 percent. As we discuss further below, part of this is attributable to the exit of inefficient plants, and part is a within effect.

Pavcnik's study of Chilean trade liberalization has spurred studies on other (unilateral) trade liberalizations, including Indonesia (Amiti \& Konings 2007), Columbia (Fernandes 2007), India (Sivadasan 2009), and Brazil (Ferreira \& Rossi 2003). These studies' findings are similar to those of Pavcnik's.

Ruiz \& Utar (2009) examine the impact of productivity of Mexican (maquiladoras) manufacturing plants when China entered the World Trade Organization (WTO) in 2001. Chinese plants provided a competitive threat to these Mexican plants in the United States, and the threat increased with WTO entry. The authors find that the Mexican plants that were most susceptible to Chinese competition had the greatest productivity gains on China's WTO entry.

Trefler (2004) is a leading paper examining the impact on labor productivity of Canadian plants of the tariff reductions that grew out of the Canada-U.S. free trade agreement. ${ }^{13}$ This is a particularly clean case to look at, since the tariff changes were not accompanied by other reforms, and so the impact of the tariffs is not commingled with the effects of other changes. ${ }^{14}$ Trefler found

\footnotetext{
${ }^{13}$ These are not unilateral tariff reductions like those above, but Trefler has information on both sets of tariffs and can control for U.S. tariffs against Canada.

${ }^{14} \mathrm{~A}$ caveat about analyses of trade liberalizations taking place in developing countries (such as the case of Chile above) is that other reforms typically take place at the same time.
} 
the tariff reductions led to substantial increases in labor productivity both at the industry level and within plants.

It's worth taking a moment to describe how the literature typically calculates the within-plant productivity gains from trade liberalizations. There are two steps. In the first, studies typically derive estimates of a plant's TFP, say $\hat{A}_{i t}$, for plant $i$ at time $t$. In the second, they then run simple regressions such as

$$
\hat{A}_{i t}=\alpha_{i}+\gamma_{t}+\beta \cdot(\text { tariff })_{i t}+\varepsilon_{i t}
$$

where $(\text { tariff })_{i t}$ is the tariff protection enjoyed by plant $i$ at time $t$, and $\alpha_{i}$ and $\gamma_{t}$ are fixed plant and time effects. Nearly all studies find $\beta<0$, suggesting a within-plant effect.

In the first step, significant econometric issues are involved in estimating plant TFP, $\hat{A}_{i t}$, and the literature has made good progress overcoming them. For example, suppose the production function is Cobb-Douglas,

$$
y_{i t}=A_{i t}\left(n_{i t}\right)^{\theta_{n}}\left(m_{i t}\right)^{\theta_{m}}\left(k_{i t}\right)^{\theta_{k}}
$$

for inputs $n_{i t}, m_{i t}$, and $k_{i t}$ (employment, materials, and capital). Given outputs and inputs, with estimates of $\hat{\theta}=\left(\hat{\theta}_{n}, \hat{\theta}_{m}, \hat{\theta}_{k}\right)$, we can back out an estimate of the TFP variable $\hat{A}_{i t}$ for firm $i$ at time t. But there are significant econometric issues in estimating the production function coefficients correctly. Olley \& Pakes (1996) and subsequent papers such as Levinsohn \& Petrin (2003) propose methods for estimating $\theta$ that address the econometric issues of simultaneity in the choice of inputs and selection from entry and exit. De Loecker (2009) extends these methods by taking into account that markups are endogenous.

In the second step, given the estimates $\hat{A}_{i t}$, the literature then estimates the regression (2). At this point, the literature tends to stop worrying about the selection issues it was concerned with during the first stage when the input coefficients $\theta$ were estimated. These papers estimate $\beta$ by 
comparing plants over time, i.e., plants that survive from one period to the next. But we expect survival to be related to changes in productivity over time. If tariffs are decreasing over time, this selection can lead to a negative estimate of $\beta$ with ordinary least squares (OLS) even when $\beta=0 .{ }^{15}$

We are not sure how important this selection is when estimating the regression (2). As discussed above in the studies of particular industries, it would be nice to explicitly link the changes in competition (here, tariff reductions) with changes taking place within the surviving plants besides productivity (such as the changes in labor contracts in the iron ore and cement industries). This would show that the productivity changes taking place within the plants would likely not have taken place without the reduction in tariffs. Some studies are starting to look inside the plants (e.g., examining if the mix of products produced in plants changes with trade liberalization).

As we said, most of the literature has found that as tariffs are cut, plants become more productive. One study that finds the opposite is Konings \& Vandenbussche (2008). The paper examines the relationship between antidumping protection and productivity. When a firm receives antidumping protection, punitive duties are imposed on imports in the firm's industry from particular countries (those found guilty of dumping the industry product). The paper has two main results. First, firms getting antidumping protection tend to be less productive than firms that are similar in other respects (call these other firms "peer firms"). Second, the productivity gap between the protected firms and their peers actually declines (but never disappears) after the protections are imposed. This is an intriguing finding because it goes in the opposite direction of the results reported above. The results, at first sight, suggest that adding trade protection (thereby reducing competition) raises productivity. But now consider the selection of firms that win antidumping cases. These invariably are firms that are getting hammered in the marketplace by imports. The within-productivity gains that these firms experience could very well be driven by the increased

\footnotetext{
${ }^{15}$ Pavcnik (2002) includes a dummy variable for exit in a regression that is analogous to (2), but there is no reason to expect this correction to lead to a consistent estimate of $\beta$.
} 
competition they face rather than the increased protection they win in trade commission filings. ${ }^{16}$

\subsection{Common Markets}

Although most of the studies of trade liberalization have been unilateral tariff cuts, there are some studies of situations where countries reduce tariffs together. This typically happens when common markets are formed. McGrattan \& Prescott (2009) look at the aggregate labor productivity of European countries before and after they join the European Union. They show that the productivity of joining countries falls relative to the United States before membership in the union and then begins to increase after joining (see their Figures 1-3). The impact of increased competition may well have been one source of the productivity increases. The impact of bigger markets may have been another (see Bottasso \& Sembenelli 2001, Bustos 2010).

\section{CONCLUSION}

We have reviewed a new literature that has examined industries experiencing dramatic changes in their competitive environment. Nearly all the studies found that increases in competition led to increases in industry productivity. Plants that survived these increases in competition were typically found to have large productivity gains, and these gains often accounted for the majority of overall industry gains.

There remains a big challenge to understand these X-efficiency or within-plant productivity gains following increased competition. There have been some interesting papers to be sure (such as Schmidt 1997 and Raith 2003), but no model has been accepted as a workhorse model.

Some interesting ideas have come out of the detailed industry studies above-ideas that may help in building such a workhorse model. One idea is that one cost of investment is the opportunity cost of lost profits from delayed or lost sales when adopting technology (if there are switchover

\footnotetext{
${ }^{16}$ For example, the U.S. cement industry filed, and won, antidumping cases in the 1980s when imports were surging in the United States. It's pretty clear that the impressive productivity gains in the industry were driven by the competition, not by the antidumping cases the industry won.
} 
disruptions). Since competition reduces this opportunity cost, it is a force for investment (even if a plant's potential market is shrinking). Holmes et al. (2008) have formalized these ideas.

Another phenomenon (unexpectedly) emerged from these studies. It was found that firms that had the opportunity to create markets in which they would have great market power were reluctant to do so. The executives realized that if they built the plants to produce the goods, they would be susceptible to very high tax rates from various levels of government, and also to very high wages from unions. And this would be the case precisely because the firm would have no competitors.

The case illustrates another reason why monopoly may be bad for investment and innovation, since if a firm has no competitors, then its input suppliers have a great incentive to invest in their own market power and thereby extract surplus from the firm's innovations. ${ }^{17}$ This finding is similar to results stressed in the hold-up literature (see also Van Reenen 1996, who shows in a panel of firms that innovation is usually followed by increasing wages).

\footnotetext{
${ }^{17}$ See Boldrin \& Levine (2008), who discuss other reasons why market power may be a threat to innovation.
} 


\section{References}

Aghion P, Bloom N, Blundell R, Griffith R, Howitt P. 2005. Competition and innovation: an inverted-U relationship. Q. J. Econ. 120(2): 701-28

Amiti M, Konings J. 2007. Trade liberalization, intermediate inputs, and productivity: evidence from Indonesia. Am. Econ. Rev. 97(5): 1611-38

Arrow K. 1962. Economic welfare and the allocation of resources for inventions. In The Rate and Direction of Inventive Activity, ed. R Nelson. Princeton, NJ: Princeton Univ. Press

Bailey M, Hulten C, Campbell D. 1992. Productivity dynamics in manufacturing plants. In Brookings Papers on Economic Activity: Microeconomics, 4: 187-267. Washington, DC: Brookings Inst.

Bain J. 1951. Relation of profit rate to industry concentration: American manufacturing, 1936-40. Q. J. Econ. 65(3): 293-324

Bloom N, Draca M, Van Reenen J. 2008. Trade induced technical change? The impact of Chinese imports on IT and innovation. Work. Pap., Dept. Econ., Stanford Univ.

Bloom N, Van Reenen J. 2007. Measuring and explaining management practices across firms and countries. Q. J. Econ. 122(4): 1351-1408

Boldrin M, Levine D. 2008. Against Intellectual Monopoly. Cambridge: Cambridge Univ. Press

Bottasso A, Sembenelli A. 2001. Market power, productivity and the EU single market program: evidence from a panel of Italian firms. Europ. Econ. Rev. 45(1): 167-86

Bresnahan T, Reiss P. 1991. Entry and competition in concentrated markets. J. Polit. Econ. 99(5): 997-1009

Bridgman B, Qi S, Schmitz JA Jr. 2009. The economic performance of cartels: evidence from the New Deal U.S. sugar manufacturing cartel, 1934-74. Staff Rep. 437, Fed. Reserve Bank Minneapolis 
Bustos, P. 2010. Trade liberalization, exports, and technology upgrading: evidence on the impact of MERCOSUR on Argentinean firms. Am. Econ. Rev. In press

Cappelli P. 1990. Still working on the railroad: an exception to the transformation of labor relations. Work. Pap., Wharton School, Univ. Penn.

Collard-Wexler A. 2010. Productivity dispersion and plant selection in the ready-mix concrete industry. Work. Pap., Dept. Econ., New York Univ.

Copeland A, Shapiro A. 2010. The impact of competition on technology adoption: an apples-to-PCs analysis. Work. Pap., Fed. Reserve Bank New York

Davis EW. 1964. Pioneering with Taconite. St. Paul: Minn. Hist. Soc.

De Loecker J. 2009. Product differentiation, multi-product firms and estimating the impact of trade liberalization on productivity. Work. Pap., Princeton Univ.

Demsetz H. 1973. Industry structure, market rivalry, and public policy. J. Law Econ. 16(1): 1-9

Dunne T, Klimek S, Schmitz JA Jr. 2008. Does foreign competition spur productivity? Evidence from post WWII U.S. cement manufacturing. Work. Pap., Fed. Reserve Bank Minneapolis

Fabrizio K, Rose N, Wolfram C. 2007. Do markets reduce costs? Assessing the impact of regulatory restructuring on U.S. electric generation efficiency. Am. Econ. Rev. 97(4): 1250-77

Fernandes AM. 2007. Trade policy, trade volumes and plant-level productivity in Colombian manufacturing industries. J. Int. Econ. 71(1): 52-71

Ferreira PC, Rossi JL. 2003. New evidence from Brazil on trade liberalization and productivity growth. Int. Econ. Rev. 44(4): 1383-1405

Fogel R. 1964. Railroads and American Economic Growth: Essays in Econometric History. Baltimore: John Hopkins Press

Fogel R. 1979. Notes on the social saving controversy. J. Econ. Hist. 39(1): 1-54

Galdon-Sanchez JE, Schmitz JA Jr. 2002. Competitive pressure and labor productivity: world 
iron-ore markets in the 1980s. Am. Econ. Rev. 94(4): 1222-35

Goettler R, Gordon B. 2009. Does AMD spur intel to innovate more? Work. Pap., Univ. Chicago

Haskel J, Sanchis A. 1995. Privatisation and X-inefficiency: a bargaining approach. J. Ind. Econ. 43(3): 301-21

Haskel J, Szymanski S. 1993. Privatization, liberalization, wages and employment: theory and evidence for the UK. Economica, N. S., 60(238): 161-81

Hester H. 1896. Cotton: its relation to American seaports, past and present. Mfrs. Rec.

Holmes T, Schmitz JA Jr. 1995. Resistance to new technology and trade between areas. Fed. Reserve Bank Minneapolis Quart. Rev. 19(1): 2-17

Holmes T, Schmitz JA Jr. 2001. Competition at work: railroads vs. monopoly in U.S. shipping. Fed. Reserve Bank Minneapolis Quart. Rev. 25(2): 3-29

Holmes T, Levine D, Schmitz J. 2008. Monopoly and the incentive to innovate when adoption involves switchover disruptions. Work. Pap. 402, Fed. Reserve Bank Minneapolis

Hopenhayn H. 1992. Entry, exit, and firm dynamics in long run equilibrium. Econometrica 60(5): $1127-50$

Hsieh C-T, Klenow P. 2007. Misallocation and manufacturing TFP in China and India. Work. Pap., Natl. Bureau Econ. Res.

Killingsworth C. 1962. The modernization of West Coast longshore work rules. Ind. Lab. Relat. Rev. 15(3): 295-306

Klein B, Crawford R, Alchian A. 1978. Vertical integration, appropriable rents, and the competitive contracting process. J. Law Econ. 21(2): 297-326

Konings J, Vandenbussche H. 2008. Heterogeneous responses of firms to trade protection. J. Int. Econ. 76(2): 371-83

Kossoris M. 1961. Working rules in West Coast longshoring. Mon. Lab. Rev. 
Krueger A, Mas A. 2004. Strikes, scabs, and tread separations: labor strife and the production of defective Bridgestone/Firestone tires. J. Polit. Econ. 112(2): 253-89

Lambson V. 1992. Competitive profits in the long run. Rev. Econ. Stud. 59(1): 125-42

Leibenstein, H. 1966. Allocative efficiency vs. "X-efficiency." Am. Econ. Rev. 56(3): 392-415

Levinsohn J, Petrin A. 2003. Estimating production functions using inputs to control for unobservables. Rev. Econ. Stud. 70(2): 317-41

Macieira J. 2009. A dynamic model of innovation and technological competition in the supercomputer industry. Work. Pap., Dept. Econ., Virginia Tech

Mankiw NG, Whinston M. 1986. Free entry and social inefficiency. RAND J. Econ. 17(1): 48-58

Matsa D. 2009. Competition and product quality in the supermarket industry. Work. Pap., Dept. Finance, Northwestern Univ.

McGrattan E, Prescott E. 2009. Openness, technology capital, and development. J. Econ. Theory 144(6): $2454-76$

Nickell S. 1996. Competition and corporate performance. J. Polit. Econ. 104(4): 726-46

Northrup H. 1989. From union hegemony to union disintegration: collective bargaining in cement and related industries. J. Lab. Res. 10(4): 337-76

Olley S, Pakes A. 1996. The dynamics of productivity in the telecommunications equipment industry. Econometrica 64(6): 1263-97

Pakes A, Ostrovsky M, Berry S. 2007. Simple estimators for the parameters of discrete dynamic games, with entry/exit examples. RAND J. Econ. 38(2): 373-99

Pavcnik N. 2002. Trade liberalization, exit, and productivity improvements: evidence from Chilean plants. Rev. Econ. Stud. 69(1): 245-76

Prescott E. 1998. Needed: a theory of TFP. Int. Econ. Rev. 39(3): 525-51

Raith M. 2003. Competition, risk, and management incentives. Am. Econ. Rev. 93(4): 1425-36 
Ruiz L, Utar H. 2009. The impact of Chinese competition on Mexican maquiladoras: evidence from plant-level panel data. Work. Pap., Univ. Colorado

Salinger M. 1984. Tobin's q, unionization, and the concentration-profits relationship. RAND J. Econ. 15(2): 159-70

Schmidt K. 1997. Managerial incentives and product market competition. R. Econ. Stud. 64(2): $191-213$

Schmitz JA Jr. 2005. What determines productivity? Lessons from the dramatic recovery of the U.S. and Canadian iron ore industries following their early 1980s crisis. J. Polit. Econ. 113(3): 582-625

Schumpeter J. 1942. Capitalism, Socialism and Democracy. New York: Harper and Row

Sivadasan J. 2009. Barriers to competition and productivity: evidence from India. B.E. J. Econ. Anal. Pol. 9(1) (Advances): art. 42

Stigler G. 1956. Industrial organization and economic progress. In The State of the Social Sciences, ed. L White. Chicago: Univ. Chicago Press

Stigler, GJ. 1976. The xistence of X-efficiency. Am. Econ. Rev. 66(1): 213-16

Sutton J. 2007. Market structure: theory and evidence. In Handbook of Industrial Organization, ed. M Armstrong, R Porter, 3:2301-68. Amsterdam: Elsevier

Symeonidis G. 2008. The effect of competition on wages and productivity: evidence from the United Kingdom. Rev. Econ. Statist. 90(1): 134-46

Syverson C. 2004. Market structure and productivity: a concrete example. J. Polit. Econ. 112(6): $1181-222$

Trefler D. 2004. The long and short of the Canada-U.S. free trade agreement. Am. Econ. Rev. 94(4): 870-95

Tybout J, de Melo J, Corbo V. 1991. The effects of trade reforms on scale and technical efficiency: 
new evidence from Chile. J. Int. Econ. 31(3-4): 231-50

Tybout J, Westbrook D. 1995. Trade liberalization and the dimensions of efficiency change in Mexican manufacturing industries. J. Int. Econ. 39(1-2): 53-78

Van Reenen J. 1996. The creation and capture of rents: wages and innovation in a panel of U.K. companies. Q. J. Econ. 111(1): 195-226

Vives X. 2008. Innovation and competitive pressure. J. Ind. Econ. 56(3): 419-69

Vogel J. 2008. Spatial competition with heterogeneous firms. J. Polit. Econ. 116(3): 423-66

Williamson O. 1979. Transaction cost economics: the governance of contractual relations. J. Law Econ. 22(2): 233-61

Xu DY. 2008. A structural empirical model of RESD, firm heterogeneity, and industry evolution. Work. Pap., Dept. Econ., New York Univ. 